\title{
Profil kejang demam di Bagian Ilmu Kesehatan Anak RSUP Prof. Dr. R. D. Kandou Manado periode Januari 2014 - Juni 2016
}

\author{
${ }^{1}$ Jenyfer P. Kakalang \\ ${ }^{2}$ Nurhayati Masloman \\ ${ }^{2}$ Jeanette I. Ch. Manoppo
}

\author{
${ }^{1}$ Kandidat Skripsi Fakultas Kedokteran Universitas Sam Ratulangi Manado \\ ${ }^{2}$ Bagian Ilmu Kesehatan Anak Fakultas Kedokteran Universitas Sam Ratulangi Manado \\ Email: jenyferkakalang@gmail.com
}

\begin{abstract}
Febrile seizure usually occurs during increased body temperature (rectal temperature $>38^{0} \mathrm{C}$ ) caused by an extracranial process. Although febrile seizure is not a neurological disorder, it occurs most common among children. This study was aimed to obtain the profile of febrile seizure in children. This was a descriptive retrospective study. This study was conducted at the Department of Pediatrics Prof. Dr. R. D. Kandou Hospital from January 2014 to June 2016. The results showed that there were 150 children diagnosed as febrile seizure. The majority of them were as follows: age group of $1-<2$ years old in 41 children $(27.3 \%)$, males $(50.7 \%)$, family history in 104 children $(69.3 \%)$, respiratory tract infection as the cause of fever in 68 children (45.3\%); complex febrile seizure in 91 children (60.7\%); normal birth weight in 135 children (90\%); normal nutritional status in 101 children (67.3\%); and spontaneous delivery with head presentastion ins 127 children (84.7\%). Conclusion: In this study, febrile seizure was most common among boys and diagnosed as complex febrile seizure.
\end{abstract}

Keywords: febrile seizures, body temperature, extracranial, children

\begin{abstract}
Abstrak: Kejang demam ialah bangkitan kejang yang terjadi pada kenaikan suhu tubuh (suhu rektal $>38^{0} \mathrm{C}$ ) yang disebabkan oleh suatu proses ekstrakranial. Walalupun kejang demam bukan merupakan suatu kelainan neurologis tetapi keadaan ini sering dijumpai pada anak. Penelitian ini bertujuan untuk mengetahui profil kejang demam pada anak. Jenis penelitian ialah deskriptif retrospektif untuk mengetahui profil kejang demam di Bagian Ilmu Kesehatan Anak RSUP Prof. Dr. R. D. Kandou periode Januari 2014 sampai Juni 2016. Hasil penelitian mendapatkan 150 anak yang didiagnosis kejang demam. Kejang demam paling sering ditemukan pada usia $1-<2$ tahun berjumlah 41 anak $(27,3 \%)$; jenis kelamin laki-laki berjumlah 99 anak (66\%); suhu badan $>38^{\circ} \mathrm{C}$ berjumlah 76 anak $(50,7 \%)$; adanya riwayat keluarga 104 anak (69,3\%); penyakit yang mendasari infeksi saluran pernafasan berjumlah 68 anak (45,3\%); jenis kejang demam kompleks 91 anak (60,7\%); berat badan lahir normal 135 anak (90\%); status gizi normal 101 anak (67,3\%); riwayat jenis persalinan spontan LBK 127 anak (84,7\%). Simpulan: Kejang demam paling sering terjadi pada anak laki-laki dan diagnosis jenis kejang demam kompleks.
\end{abstract}

Kata kunci: kejang demam, suhu tubuh, ekstrakranial, anak

Kejang demam ialah bangkitan kejang yang terjadi pada kenaikan suhu tubuh (suhu rectal lebih dari $38^{\circ} \mathrm{C}$ ) yang disebabkan oleh suatu proses ekstrakranial. ${ }^{1}$ Kejang demam bukan merupakan suatu kelainan neurologis tapi paling sering dijumpai pada anak. Berdasarkan kriteria Livingstone kejang demam terjadi terutama pada 
golongan usia 6 bulan dan 4 tahun. $^{2}$ Angka kejadian kejang demam di Indonesia sendiri mencapai 2-4\% tahun 2008 dan terjadi pada anak antara usia 6 bulan dan 7 tahun, dan setengahnya yang terjadi antara usia 1 dan 2 tahun $80 \%$ disebabkan oleh infeksi saluran pernafasan. Bila terjadi pada usia kurang dari 6 bulan harus dipikirkan penyebab lain seperti infeksi susunan saraf pusat maupun epilepsi yang terjadi bersama demam. ${ }^{3}$ Kejang demam tanpa komplikasi merupakan kejang menyeluruh yang berlangsung kurang dari 15 menit yang terjadi hanya sekali dalam masa 24 jam. Jika bersifat fokal, lama, atau multipel, kejang tersebut dinamakan kejang demam kompleks. $^{4}$

Faktor yang penting pada kejang demam ialah demam, usia, genetik, prenatal dan perinatal. Demam sering disebabkan infeksi saluran pernapasan atas, otitis media, pneumonia, gastroenteritis dan infeksi saluran kemih. ${ }^{5}$ Pada penelitian yang dilakukan oleh Wegman dan Millichap menggunakan hewan coba disimpulkan bahwa suhu tinggi dapat menyebabkan terjadinya kejang. Terjadinya bangkitan kejang demam bergantung kepada usia, tinggi serta cepatnya suhu meningkat. ${ }^{1}$

WHO memperkirakan pada tahun 2005 terdapat lebih dari 21,65 juta penderita kejang demam dan lebih dari 216 ribu diantaranya meninggal. Angka kejadian kejang demam bervariasi diberbagai negara. Daerah Eropa Barat dan Amerika tercatat 2-4\% angka kejadian kejang demam per tahunnya. Sedangkan di India sebesar 5-10\% dan di Jepang 8,8\%. Hampir $80 \%$ kasus kejang demam sederhana (kejang <15 menit, umum, tonik atau klonik, akan berhenti sendiri, tanpa gerakan fokal atau berulang dalam waktu 24 jam) sedangkan $20 \%$ kasus merupakan kejang demam komplikata (kejang >15 menit, fokal atau kejang umum didahului kejang parsial, berulang atau lebih dari satu kali dalam 24 jam). ${ }^{6}$

Sebagian besar kasus kejang demam sembuh sempurna tetapi 2\%-7\% berkembang menjadi epilepsi dengan angka kematian $0,64 \%-0,75 \%$. Kejang demam dapat mengakibatkan gangguan tingkah laku serta penurunan intelegensi dan pencapaian tingkat akademik. Beberapa hasil penelitian tentang penurunan tingkat intelegensi paska bangkitan kejang demam tidak sama, 4\% pasien kejang demam secara bermakna mengalami gangguan tingkah laku dan penurunan tingkat intelegensi. ${ }^{9}$ Prognosis kejang demam baik, namun bangkitan kejang demam cukup mengkhawatirkan bagi orang tuanya. ${ }^{5}$

\section{METODE PENELITIAN}

Jenis penelitian ini ialah deskriptif retrospektif untuk mengetahui adanya profil kejang demam di bagian Ilmu Kesehatan Anak RSUP Prof. Dr. R. D. Kandou periode Januari 2014 sampai Juni 2016. Sampel penelitian ialah semua anak yang didiagnosis kejang demam yang diambil dari rekam medik rumah sakit pada periode Januari 2014 sampai dengan Juni 2016 Bagian Ilmu Kesehatan Anak BLU RSUP Prof. Dr. R. D. Kandou Manado.

Variabel penelitian ialah usia, jenis kelamin, suhu badan, riwayat keluarga, riwayat penyakit yang mendasari, jenis kejang demam, berat badan lahir, riwayat jenis persalinan, dan status gizi. Pengolahan data dilakukan secara manual. Analisis data merupakan analisis univariat.

\section{HASIL PENELITIAN}

Berdasarkan penelitian yang dilakukan secara retrospektif di RSUP Prof. Dr. R. D. Kandou Manado di Bagian Ilmu Kesehatan Anak selama Januari 2014 - Juni 2016, didapatkan 150 sampel penelitian.

Tabel 1. Distribusi penderita kejang demam berdasarkan golongan usia

\begin{tabular}{cc}
\hline Golongan usia & Jumlah $(\%)$ \\
\hline 6 bulan $-<1$ tahun & $30(20)$ \\
$1-<2$ tahun & $41(27,3)$ \\
$2-<3$ tahun & $35(23,3)$ \\
$3-4$ tahun & $27(18)$ \\
$4-<5$ tahun & $17(11,3)$ \\
Total & $150(100)$ \\
\hline
\end{tabular}


Tabel 2. Distribusi penderita kejang demam berdasarkan jenis kelamin

\begin{tabular}{cc}
\hline Jenis kelamin & Jumlah (\%) \\
\hline Laki-laki & $99(66)$ \\
Perempuan & $51(34)$ \\
Total & $150(100)$ \\
\hline
\end{tabular}

Tabel 3. Distribusi penderita kejang demam berdasarkan suhu badan

\begin{tabular}{cc}
\hline Suhu badan & Jumlah (\%) \\
\hline Dibawah $38^{\circ} \mathrm{C}$ & $74(49,3)$ \\
Diatas $38^{\circ} \mathrm{C}$ & $76(50,7)$ \\
Total & $150(100)$ \\
\hline
\end{tabular}

Tabel 4. Distribusi penderita kejang demam berdasarkan riwayat keluarga

\begin{tabular}{cc}
\hline Riwayat keluarga & Jumlah (\%) \\
\hline Ayah & $23(15,3)$ \\
Ibu & $6(4)$ \\
Saudara kandung & $17(11,3)$ \\
Hanya penderita & $104(69,3)$ \\
Total & $150(100)$ \\
\hline
\end{tabular}

Tabel 5. Distribusi penderita kejang demam berdasarkan penyakit yang mendasari

\begin{tabular}{cc}
\hline Riwayat keluarga & Jumlah (\%) \\
\hline Infeksi saluran pernafasan & $74(49,3)$ \\
akut & $40(26,7)$ \\
Gastroenteritis & $2(1,3)$ \\
Otitis media akut & $4(2,7)$ \\
Infeksi saluran kemih & $30(20)$ \\
Dan lain-lain & \\
Total & $150(100)$ \\
\hline
\end{tabular}

Tabel 6. Distribusi penderita kejang demam berdasarkan klasifikasi kejang

\begin{tabular}{cc}
\hline Jenis kejang demam & Jumlah (\%) \\
\hline KDS & $59(39,3)$ \\
KDK & $91(60,7)$ \\
Total & $150(100)$ \\
\hline
\end{tabular}

Tabel 7. Distribusi penderita kejang demam berdasarkan berat badan lahir

\begin{tabular}{cc}
\hline BBL & Jumlah (\%) \\
\hline BBLR & $13(8,7)$ \\
Normal & $135(90)$ \\
Makrosomia & $2(1,3)$ \\
Total & $150(100)$ \\
\hline
\end{tabular}

Tabel 8. Distribusi penderita kejang demam berdasarkan status gizi

\begin{tabular}{cc}
\hline Status Gizi & Jumlah (\%) \\
\hline Gizi buruk & $2(1,3)$ \\
Gizi kurang & $11(7,3)$ \\
Normal & $101(67,3)$ \\
Overweight & $23(15,3)$ \\
Obesitas & $13(8,7)$ \\
Total & $150(100)$ \\
\hline
\end{tabular}

Tabel 9. Distribusi penderita kejang demam berdasarkan riwayat jenis persalinan

\begin{tabular}{cc}
\hline Riwayat Persalinan & Jumlah (\%) \\
\hline Operasi seksio & $23(15,3)$ \\
Spontan LBK & $127(84,7)$ \\
Total & $150(100)$ \\
\hline
\end{tabular}

\section{BAHASAN}

Hasil penelitian menunjukkan bahwa dari 150 orang anak golongan usia terbanyak ialah usia $1-<2$ tahun yang berjumlah 41 anak $(27,3 \%)$, diikuti usia 2 $<3$ tahun berjumlah 35 anak $(23,3 \%)$, usia 6 bulan - <1 tahun berjumlah 30 anak (20\%), usia 3-4 tahun berjumlah 27 anak (18\%), dan usia $4-<5$ tahun berjumlah 17 anak (11,3\%) (Tabel 1).

Pada penelitiannya di Bangsal Anak RSUP Dr. M. Djamil Imaduddin et al. ${ }^{7}$ menyebutkan kasus kejang demam paling banyak terjadi pada kelompok usia $\geq 6$ bulan $-<1$ tahun dan $\geq 1$ tahun $-<2$ tahun yaitu masing-masing sebanyak 13 kasus $(25,5 \%)$. Millichap juga menyatakan bahwa anak yang berusia 1-2 tahun paling sering menderita kejang demam dengan presentasi yaitu $43 \% .{ }^{1}$ Hasil ini bertentangan dengan penelitian oleh Lumbantobing yang menemukan anak berusia <1 tahun sebagai kelompok usia yang paling sering menderita kejang demam $(56,7 \%){ }^{8}$

Pada penelitian ini didapatkan bahwa anak laki-laki dengan kejang demam lebih banyak (66\%) dibandingkan dengan anak perempuan (34\%) (Tabel 2) Hasil penelitian ini sejalan dengan penelitian oleh Nurindah et al. ${ }^{9}$ yang mendapatkan bahwa kejang demam lebih banyak terjadi pada anak laki-laki $(68,42 \%)$ dibandingkan dengan anak perempuan $(31,58 \%)$. 
Bakry et al. ${ }^{10}$ melakukan penelitian di Departemen Ilmu Kesehatan Anak FKUI RS. Dr. Cipto Mangunkusumo juga mendapatkan bahwa anak laki-laki lebih sering terkena kejang demam (59 anak) dibandingkan anak perempuan (41 anak). Rasio ini sejalan dengan hasil penelitian Millar $^{11}$ tentang perbandingan penderita kejang demam laki-laki dan perempuan yaitu sebesar 1,4:1.

Berdasarkan Tabel 3 didapatkan bahwa suhu badan $>38^{\circ} \mathrm{C}$ mempunyai angka sedikit lebih tinggi yaitu berjumlah 76 anak $(50,7 \%)$ dibandingkan dengan suhu badan $<38^{\circ} \mathrm{C}$ yang berjumlah 74 anak $(49,3 \%)$. Penelitian ini sejalan dengan hasil penelitian yang dilakukan oleh Gunawan PI et al. ${ }^{6}$ yang melaporkan bahwa suhu badan dengan kejang demam $>38^{\circ} \mathrm{C}$ sedikit lebih tinggi yaitu 57 orang $(70,4 \%)$ dibandingkan dengan suhu badan $<38^{\circ} \mathrm{C}$ yang berjumlah 8 orang $(42,1 \%)$. Hasil yang serupa juga didapatkan pada penelitian oleh Ling $^{12}$ terhadap 379 anak dengan diagnosa kejang demam yaitu yang mengalami kejang demam lebih banyak terjadi pada suhu $>38^{\circ} \mathrm{C}$ dengan jumlah 257 anak sedangkan pada suhu badan $<38^{\circ} \mathrm{C}$ berjumlah 120 anak. Berdasarkan acuan pustaka $11 \%$ anak dengan kejang demam mengalami kejang pada suhu $<37,9^{\circ} \mathrm{C}$, sedangkan $14-40 \%$ kejang terjadi pada suhu antara $38^{\circ}-38,9^{\circ} \mathrm{C}$, dan $40-56 \%$ pada suhu antara $39^{\circ} \mathrm{C}$ $39,9^{\circ} \mathrm{C} .{ }^{13}$

Berdasarkan Tabel 4 yang terbanyak didapatkan ialah anak tanpa adanya riwayat keluarga atau hanya penderita dengan jumlah 104 anak (69,3\%), diikuti dengan orang tua (ayah) berjumlah 23 orang $(15,3 \%)$, dan saudara kandung dengan riwayat kejang demam berjumlah 17 orang $(11,3 \%)$, dan data yang paling rendah ialah orang tua (ibu) dengan riwayat kejang demam 6 orang $(4 \%)$.

Penelitian yang dilakukan oleh Faudi et al. ${ }^{14}$ juga mendapatkan jumlah terbanyak terdapat pada anak yang dengan tanpa adanya riwayat keluarga atau hanya penderita dengan jumlah 70 anak $(85,4 \%)$, Terdapat perbedaan hasil penelitian selanjutnya yaitu anak dengan kejang demam dan mempunyai riwayat orang tua (ayah) pada penelitian ini hanya berjumlah 1 orang $(1,2 \%)$, diikuti dengan riwayat orang tua (ibu) yang sedikit lebih tinggi berjumlah 6 orang $(7,3 \%)$, dan saudara kandung dengan riwayat kejang demam berjumlah 5 orang $(6,1 \%)$. Selain itu, Bahtera $^{15}$ dalam penelitiannya juga melaporkan bahwa penderita kejang demam dengan keluarga mempunyai riwayat pernah menderita kejang demam, masing-masing ibu $16,2 \%$, ayah $11,5 \%$, saudara kandung 6,8\%.

Berdasarkan Tabel 5 dapat dilihat bahwa pada infeksi saluran pernafasan akut mempunyai jumlah anak terbanyak (49,3\%). Fakta yang sama juga dikemukakan dalam penelitian lain tapi dengan angka yang lebih besar oleh Nindela et al. ${ }^{16}$ yang mendapatkan jumlah anak menderita infeksi saluran pernafasan akut sebanyak 161 anak (87,2\%). Penyebab kedua terbanyak ialah gastroenteritis dengan jumlah 40 anak (26,7\%), yang berbeda dengan jumlah yang diteliti oleh Nurindah et al. ${ }^{9}$ yaitu hanya 9 anak $(4,9 \%)$. Penyakit yang mendasari lainnya berjumlah 30 anak (20\%) diikuti dengan jumlah penderita infeksi saluran kemih berjumlah 4 anak $(2,7 \%)$. Hal ini berbeda dengan jumlah yang didapatkan oleh Bakry et al. ${ }^{10}$ dengan angka yang lebih besar yaitu 23 anak (23\%) dan jumlah penderita otitis media akut mempunyai angka yang paling rendah yaitu 2 anak $(1,3 \%)$.

Berdasarkan Tabel 6 didapatkan untuk klasifikasi jenis kejang demam tertinggi terjadi pada kejang demam kompleks $(60,7 \%)$, setelah itu pada kejang demam sederhana (39,3\%). Dalam penelitian sebelumnya oleh Imaduddin et al. $^{7}$ kasus kejang demam yang dirawat di bangsal anak RSUP Dr. M. Djamil Padang didapatkan sebagian besar kejang demam kompleks yaitu sebanyak 33 kasus $(64,7 \%)$, sedangkan pada kejang demam sederhana didapatkan 12 kasus (23,5\%). Terdapat perbedaan dengan penelitian yang dilakukan Friedman ${ }^{17}$ yang melaporkan bahwa $80 \%$ kasus kejang demam sederhana dan hanya sekitar 20\% kejang demam 
kompleks. Pada penelitian ini ditemukan lebih banyak kejang demam kompleks karena penentuan kasus tersebut apakah kejang demam sederhana atau kompleks didapatkan dari anamnesis keluarga pasien berupa sifat kejang (umum atau fokal), lamanya kejang, dan frekuensi kejang (berulang dalam 24 jam atau tidak). Penilaian tersebut bersifat subjektif. Keluarga pasien mungkin tidak tahu pasti berapa lama kejang terjadi karena saat terjadi kejang keluarga tidak terlalu memperhatikan waktu karena lebih mengutamakan kesehatan dan keselamatan anak serta bagaimana cara menghentikan kejang.

Berdasarkan Tabel 7 hasil penelitian yang telah dilakukan didapatkan bahwa distribusi penderita kejang demam menurut berat badan lahir yaitu pada berat badan lahir normal mempunyai jumlah terbanyak (90\%), kemudian pada dan pada anak dengan makrosomia paling rendah $(1,3 \%)$. Hal ini berbeda dengan hasil penelitian yang dilakukan oleh Fuadi et al. ${ }^{14}$ di Bagian Ilmu Kesehatan Anak RSUP Dr. Kariadi Semarang yang mendapatkan kejang demam pada berat badan lahir $<2500$ gram berjumlah 44 anak $(53,7 \%)$ sedangkan berat badan lahir $\geq 2500$ berjumlah 38 anak $(46,3 \%){ }^{14}$

Berdasarkan Tabel 8 didapatkan distribusi penderita kejang demam dengan status gizi normal yang paling banyak $(67,3 \%)$, kemudian anak dengan status gizi overweight $(15,3 \%)$, status gizi obesitas $(8,7 \%)$, status gizi kurang $(7,3 \%)$ dan paling rendah status gizi buruk $(1,3 \%)$. Untuk status gizi belum didapatkan hasil penelitian pembanding.

Berdasarkan Tabel 9 didapatkan bahwa distribusi penderita kejang demam menurut riwayat jenis persalinan yang terbanyak ialah riwayat kelahiran spontan LBK $(84,7 \%)$, dan diikuti oleh operasi sesar $(15,3 \%)$. Sampai saat ini, belum ada teori yang memaparkan mengenai hubungan faktor risiko kejang demam dengan riwayat jenis persalinan.
Berdasarkan hasil penelitian terhadap kasus kejang demam di Bagian Ilmu Kesehatan Anak RSUP Prof. DR. R.D. Kandou Manado periode Januari 2014 Juni 2016 dapat disimpulkan bahwa kejang demam lebih banyak ditemukan pada usia 1 - <2 tahun, jenis kelamin laki-laki, tanpa riwayat kekuarga, suhu badan $>38^{\circ} \mathrm{C}$, riwayat penyakit yang mendasari infeksi saluran pernapasan akut, tipe kejang demam kompleks, status gizi normal, riwayat berat badan lahir normal, serta riwayat jenis persalinan normal.

\section{SARAN}

Bagi Rumah Sakit RSUP Prof. Dr. R. D. Kandou Manado atau Para Medis, disarankan untuk memberi edukasi kepada orang tua yang memiliki anak dengan kejang demam agar dapat mencegah terjadinya infeksi yang dapat menyebabkan kejang demam.

Untuk peneliti selanjutnya disarankan untuk menganalisis faktor-faktor yang menyebabkan kejadian kejang demam pada anak.

\section{DAFTAR PUSTAKA}

1. Latief A, Napitupulu PM, Pudjiadi Antonius, Ghazali MV, Putra ST. Neurologi. In: Hassan R, Alatas H, editors. Ilmu Kesehatan Anak (4th ed). Jakarta: Bagian Ilmu kesehatan Anak FKUI, 2005; p. 847-49.

2. Al-Ansari K. Kejang dan status epileptikus. In: Lalani A, Schneeweiss, editors. Kegawatdaruratan pediatrik. Jakarta: EGC, 2011; p. 313-4.

3. Rudolph AM, Hoffman JIE, Rudolph CD. Sistem saraf. In: De Vivo DC, editor. Buku Ajar Pediatrik Rudolph Vol 3 (20th ed). Jakarta: EGC, 2006; p. 21602.

4. Lewis DW. Neurologi. In: Handryastuti S, Mangunatmadja I, editors. Nelson Ilmu Kesehatan Anak Esensial (6th ed). Indonesia: Saunders Elsevier, 2014; p. 740-3.

5. Soetomenggolo TS. Kejang demam. In: Soetomenggolo TS, Ismael S, editors. Buku Ajar Neurologi Anak (2nd ed). Jakarta: BP IDAI, 2000; p. 244-51. 
6. Gunawan PI, Saharso D. Faktor risiko kejang demam berulang pada anak. M Med Indones. 2012;46(2):75-9.

7. Imaduddin K, Syarief I, Rahmatini. Gambaran elektrolit dan gula darah pasien kejang demam yang dirawat di bangsal anak RSUP Dr. M. Djamil. Jurnal Kesehatan Andalas. 2013;2(3):127-31.

8. Lumbantobing SM. Kejang Demam. Jakarta: Balai Penerbit FKUI, 2004.

9. Nurindah D, Muid M, Retoprawiro S. Hubungan antara kadar tumor necrosis factor-alpha (TNF- $\alpha)$ plasma dengan kejang demam sederhana pada anak. Jurnal kedokteran Brawijaya. 2014;28:115-7.

10. Bakry BA, Tumbelaka AR, Chair I. Etiologi dan karakteristik demam berkepanjangan pada anak di RS. Dr. Cipto Mangunkusumo Jakarta. Sari Pediatri. 2008;10:83-7.

11. Millar JS. Evaluation and treatment of the child with febrile seizure. Am Fam Physician 2006;73:1761-4.

12. SG Ling. Clinical characteristics and risk factors for a complex first febrile convulsion. Singapore Med J. 2001;42(6):264-7.

13. Widodo DP.. Kejang Demam: Apa yang perlu diwaspadai? In: Pendidikan Kedokteran Berkelanjutan Ilmu Kesehatan Anak XLVII. Jakarta: FKUI, 2005; p. 58-66.

14. Fuadi, Bahtera T, Wijayahadi. Faktor risiko bangkitan kejang demam pada anak. Sari Pediatri. 2010;12(3):142-9.

15. Bahtera T. Faktor risiko kejang demam berulang sebagai prediktor bangkitan kejang demam berulang. Kajian mutasi gen pintu voltase kanal ion natrium. [Disertasi]. Seemarang: Fakultas Kedokteran Universitas Diponegoro; 2007.

16. Nindela R, Dewi MR, Ansori IZ. Karakteristik penderita kejang demam di instalasi rawat inap Bagian Anak Rumah Sakit Muhammad Hoesin Palembang. Jurnal Kedokteran Kesehatan. 2014;1(1):41-5.

17. Friedman MJ, Sharieff GQ. Seizures in Children. Pediatric Clinics of North America. 2006:53;257-77. 